\title{
Toward Humanistic Theories of Legal Justice
}

Robin West

Georgetown University Law Center, west@law.georgetown.edu

Georgetown Public Law and Legal Theory Research Paper No. 11-86

This paper can be downloaded free of charge from:

https://scholarship.law.georgetown.edu/facpub/669

http://ssrn.com/abstract=1865265

10 Cardozo Stud. L. \& Literature 147 (1998)

This open-access article is brought to you by the Georgetown Law Library. Posted with permission of the author. Follow this and additional works at: https://scholarship.law.georgetown.edu/facpub

Part of the Entertainment, Arts, and Sports Law Commons, Judges Commons, Jurisprudence Commons, Law and Economics Commons, and the Law and Society Commons 


\section{Toward Humanistic Theories of Legal Justice}

Robin West

In an oft-quoted aside, Justice Holmes once remarked that when lawyers in his courtroom make appeal to justice, he stops listening: such appeals do nothing but signal that the lawyer has neither the facts nor law on his side, or worse, that he is ignorant of whatever law might be relevant. ${ }^{1}$ Holmes's remark has not gone unheeded. Wary of seeming ignorant or without argument, legal scholars, legal educators, lawyers, and judges have apparently chosen to forego the task of articulating concepts of justice that might enlighten or guide the work of adjudication. Holmes, in effect, chided us out of it. Holmes's legacy, in part, is precisely this lapse: we don't have, or teach, a guiding theory of legal justice, nor do we have, or teach, a family of competing theories of legal justice, that might inform our work in law, at least as that work continues to focus on the work of courts. Nor do we have, consequently, a specifically humanistic conception of legal justice that might move adjudication in a direction conducive to the well-being and just social arrangements of the species.

There are, of course, two striking exceptions to this general claim. Working in part off a Holmesian legacy, Richard Posner and other likeminded legal economists have persuaded a sizeable percentage of two generations of lawyers that justice is wealth and wealth justice, and that this is basically all they need to know: with justice so defined, and a few analytic tools, virtually any legal problem that may confront a common law judge yields a more or less definite and wealth-maximizing solution. ${ }^{2}$ The judge interested in pursuing justice, and the lawyer interested in practicing it, need only seek the wealth-maximizing resolution of any legal dilemma. And, Ronald Dworkin, around the same period of time convinced a sizeable percentage of the same group of lawyers that justice is not essentially distinct from law itself, at least when read in the best possible light. Justice is law, one might say, and law justice, and that is all we need to know. ${ }^{3}$ The judge interested in pursuing justice, and the lawyer 
interested in practicing it, should seek and will find it in the law itself there is no meaningful moral norm, independent of the legal materials, to which he or she might turn for guidance.

There are familiar problems with both the Dworkinian and Posnerian reduction of justice to law on the one hand and wealth on the other: a law, a legal system, a legal pronouncement, a statute or a constitution, might be terribly unjust, in which case the romantic Dworkinian identification of justice with law generously understood will do little but blind us to state-sponsored injustice, and the simple pronouncement to maximize wealth, although it unquestionably quenches a thirst for certainty, might frustrate rather than serve the ends of a just order, in which case justice surely cannot be equated with wealth. I do not wish to rehearse or expand these objections here. All I want to stress is the simple point that these highly problematic, counter-intuitive, and, in some cases, seemingly cruel understandings are the only theories of legal justice - the justice that courts and lawyers and judges are committed to pursue - that have emerged, so to speak, from a point of view internal to the profession itself, and that accordingly might serve the needs of the profession. They have dominated the discussion to the extent that they have only because nature abhors a vacuum. Nevertheless, for all their power, and even given the dearth of alternatives, the Dworkinian and Posnerian understandings of justice, stated in their starkest and truest terms, have failed to persuade all but a few of us.

For those of us - probably the majority - unpersuaded that justice can or should be reduced to either the extant law, even generously read, or wealth, even ecumenically defined, the fallback position is essentially Holmesian. We discuss other regulative ideas - fairness, equity, efficiency, integrity, or, more grandly, equality or liberty - but the imperative of justice, that which a court or judge must do in order to be just, is honored only by our embarrassed failure to engage its command. This failure, in turn, has both existential and instrumental costs.

We come to law, many of us, to explore justice; furthermore, and more basically, we define our lives by this virtue. What we find when we get there is no consensus on what legal justice might mean or require. That alone, of course, is hardly cause for alarm. What is alarming, however, is that we find not only a lack of consensus but also that there is virtually no debate. There is no tradition, no shared fabric, no mosaic, no 
family of competing understandings, of what the virtue that for many of us seemingly defines our professional lives might entail. This prompts ennui, resignation, and, in our students, a cynicism we deplore but have no clue how to address in a way that does not expose our own.

The instrumental damage occasioned by our collective refusal to engage the issue is worse. The aspirations of the United States for the western rule of law are boundless: we are in the process of covering not only our country but increasingly the world with a conception of adjudicative law pointed only to the interconnected virtues of corporate wealth, individual decisional liberty, and, when not trumped by the universalist mandate of wealth, of moral and cultural relativism. The cost of our failure is ultimately the globalization of an understanding of the point of adjudicated law peculiarly unhinged from its defining virtue.

I view the contemporary interdisciplinary Law and Literature Movement, of which Cardozo Studies in Law and Literature is a foundational part, as an attempt to respond to this need. Justice, as Marianne Constable has recently reminded us, ${ }^{4}$ has always been a defining object of study of the humanities, and justice, we should remind ourselves, has always in some sense been the object or point of law and adjudication both. It is entirely natural to turn to the former to enlighten the latter. We need to rid ourselves of the twenty-five year optimistic belief that we can find in our deepest legal structures themselves a full understanding of the demands of justice, and we need to rid ourselves of the dreary belief that we can in our quest for profit find all we need to know to understand the nature of the good. But we also need to shed the stultifying skeptical and Holmesian claim that the question of justice is unbroachable, and the urge to answer it childish. The Law and Literature Movement, as I understand it, is definitively committed to the exploration of humanistic meanings of justice. The Cardozo Studies in Law and Literature, under Richard Weisberg's direction, has contributed immeasurably to that work. I have felt honored over the last ten years to be associated with it.

1 Quoted from a letter to Dr. Wu, collected in H. Shriver, ed., Oliver Wendell Holmes: His Book Notices and Uncollected Papers (1936), p. 201.

2 Richard Posner, The Economics of Justice (Cambridge: Havard University Press, 1981). 
3 Ronald Dworkin, Taking Rights Seriously (Cambridge: Havard University Press, 1978).

4 Plenary Comments at the Law, Culture and Humanities Conference, 1998, Georgetown Law Center. 